\title{
Implementácia prediktívnej údržby vretena sústruhu na základe nedeštruktívnej diagnostiky
}

\author{
Simona Hlavatá ${ }^{1}$, Adrián Vodilka ${ }^{1}$, Marek Kočiško ${ }^{1}$, Martin Pollák ${ }^{1}$ \\ 1 Technická univerzita v Košiciach, Fakulta výrobných technológií so sídlom v Prešove \\ Bayerova 1, 08001 Prešov, Slovensko \\ simona.hlavata@tuke.sk
}

\begin{abstract}
Anotácia: Hlavnou úlohou implementácie prediktívnej údržby je možnost' zníženia prestojov na vybranom zariadení. Prediktívna údržba je odvodená od slova predikovat', čiže umožňuje predpovedat' stav zariadenia v reálnom čase a predchádzat' prestojom, ktoré vznikajú na zariadeniach. Základom prediktívnej údržby je sledovanie stavu zariadení na kritických miestach. Pomocou počítača vieme dáta analyzovat' a predikovat' nadchádzajúci stav zariadenia. Nedeštruktívna diagnostika vibrodiagnostika je technická diagnostika, ktorá súvisí s prediktívnou údržbou. Ciel'om príspevku je implementovat' prediktívnu údržbu vretena sústruhu pomocou senzorov. Vd'aka aplikovaným senzorom pre kontinuálne meranie prevádzkových parametrov sústruhu je možné eliminovat' vznik porúch, ktoré negatívne ovplyvňujú výrobný proces.
\end{abstract}

\section{1 Úvod}

V súčasnosti spoločnosti viac využívajú plne automatizované stroje a výrobné linky, ktoré nahrádzajú ich predchodcov - poloautomatizovované, prípadne ručné zariadenia. Automatizované stroje majú zaistit' plynulý chod produkcie bez zbytočného zastavovania výroby. Avšak aj na automatizovaných zariadeniach môže nastat' porucha, ktorá vedie k nečakaným prestojom.

Prestojom môžeme predchádzat' pomocou preventívnej a prediktívnej údržby. Prediktívna údržba je chápaná ako čast' technickej diagnostiky, ktorá predstavuje nenahraditel'ný zdroj informácií pre zist'ovanie technického stavu objektu. Cielom prediktívnej údržby je včasná identifikácia porúch a zabezpečenie ekonomickej a bezpečnej prevádzky. Taktiež sa prediktívna údržba podiel'a na zvýšení spolahlivosti zariadení.

\section{$2 \quad$ Metodika}

Technická diagnostika sa používa pre určenie technického stavu objektu pomocou rôznych metód a prostriedkov. Vibrodiagnostika patrí medzi bezdemontážný a nedeštruktívny druh technickej diagnostiky, je založená na sledovaní a vyhodnocovaní mechanického kmitania pohyblivých, ale aj nepohyblivých časti zariadenia. Vibrácie poskytujú dobrý zdroj informácií o technickom stave daného zariadenia a sledovaním ich vývoja $v$ čase je možné analyzovat' vývoj technického stavu zariadenia v priebehu používania. 
Signál vibrácií nesie informácie o príčine vzniku vibrácií a vd’aka podrobeniu signálu rôznym metódam analýzy vieme vpredstihu odhalit' vznikajúce poškodenia zariadenia. [1]

Snímače vibrácií môžeme podla princípu merania rozdelit' na snímače absolútnych vibrácií a snímače relatívnych vibrácií. Pri meraní absolútnych vibrácií sa pohyb telesa týka gravitačného pol'a zemegule. Pokial' meriame relatívne vibrácie, dané vibrácie sa vzt'ahujú k relatívnemu bodu, napríklad $\mathrm{k}$ inej časti zariadenia.

Pri meraní vibrácií môžu byt' snímače na zariadení pripevnené trvalo, čiže dáta sa zbierajú nepretržite alebo automaticky $v$ pravidelných intervaloch. Trvalo pripevnené snímače sa využívajú na zariadeniach kritických pre prevádzku. Tieto snímače môžu byt' taktiež umiestňované do drahých zariadení priamo pri výrobe zariadenia. [2][3][4]

Pojem údržba zahŕňa celý proces činností realizovaných na technickom zariadení za účelom udržania alebo obnovenia stavu, ktorý je potrebný pre vykonávanie funkcie zariadenia. Údržba ovplyvňuje produktivitu výroby a patrí medzi najvýznamnejší proces $v$ povýrobnej fáze životného cyklu zariadenia. Prevádzkou stroja sa úžitkové vlastnosti zariadenia zhoršujú. [6]

Prediktívna údržba monitoruje výkon a stav zariadenia počas bežnej prevádzky pre zníženie pravdepodobnosti vzniku poruchy. Jedná sa o nepretržité monitorovanie strojov počas procesných podmienok. Ciel'om prediktívnej údržby je schopnost' predvídat' zlyhanie zariadenia na základe určitých faktorov a následne predchádzanie poruchy na základe pravidelnej údržby.

Klúčovým prvkom procesu je internet, ktorý umožňuje rôznym systémom spolupracovat', zdiel'at' a analyzovat' získané údaje. Údaje sú získavané zo senzorov prediktívnej údržby. Najčastejšie prediktívna údržba zahŕňa analýzu vibrácií, tribodiagnostiku a sledovanie zariadenia.

Aplikácia prediktívnej údržby je vhodná pre zariadenia, ktoré majú kritickú prevádzkovú funkciu a zlyhanie zariadenia je nákladné. [1][5]

\section{Diskusia}

Vo vybranej spoločnosti pri výrobe komponentov a následnom kontrolnom meraní zistili operátori problém s celkovým hádzaním obrobku. Hádzanie je definované ako odchýlka rotačného tvaru od teoreticky presného kruhového tvaru. Celkové hádzanie je vymedzené dvoma rovnobežnými rovinami, ktoré sú od seba vzdialené o hodnotu tolerancie. V tejto tolerančnej oblasti sa musia nachádzat' všetky body skutočného povrchu. Roviny sú kolmé k osi rotácie. V prípade prekročenia hodnôt celkového hádzania nie je diera na danom komponente súmerná a teda vzniká nepodarok. 
Pre zníženie počtu nepodarkov sme na základe analýzy celkového hádzania a skúmania dostupných grafických hodnôt určili diely, ktoré môžu vo vel'kej miere ovplyvnit' hádzanie obrobku.

Medzi tri najhlavnejšie diely, ktoré ovplyvňujú celkové hádzanie patrí čelná príruba vretena, príruba upínania a medzikus na zmiešavač. Na obrázku 1 je znázornená čelná príruba vretena (červená farba) a príruba upínania (žltá farba). Na obrázku 2 je zobrazený medzikus zmiešavača.

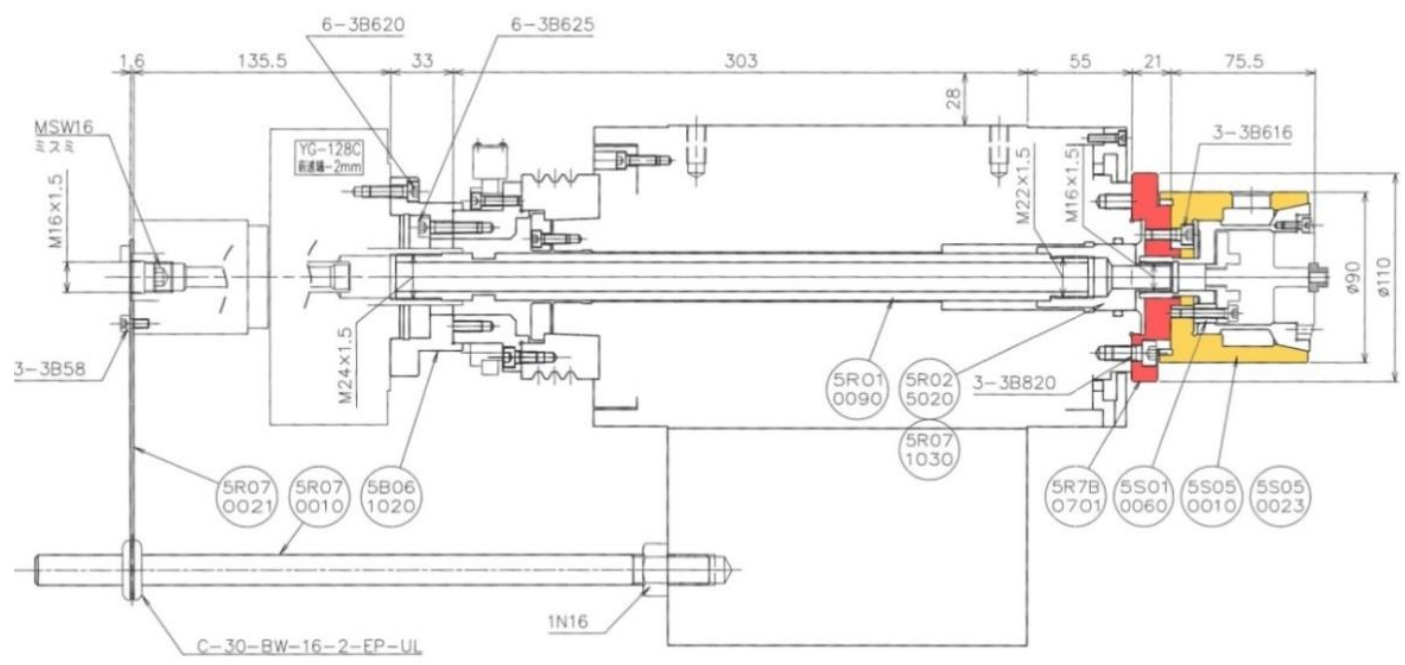

Obrázok 1 - Vytypovanie chybných dielov - príruba vretena sústruhu

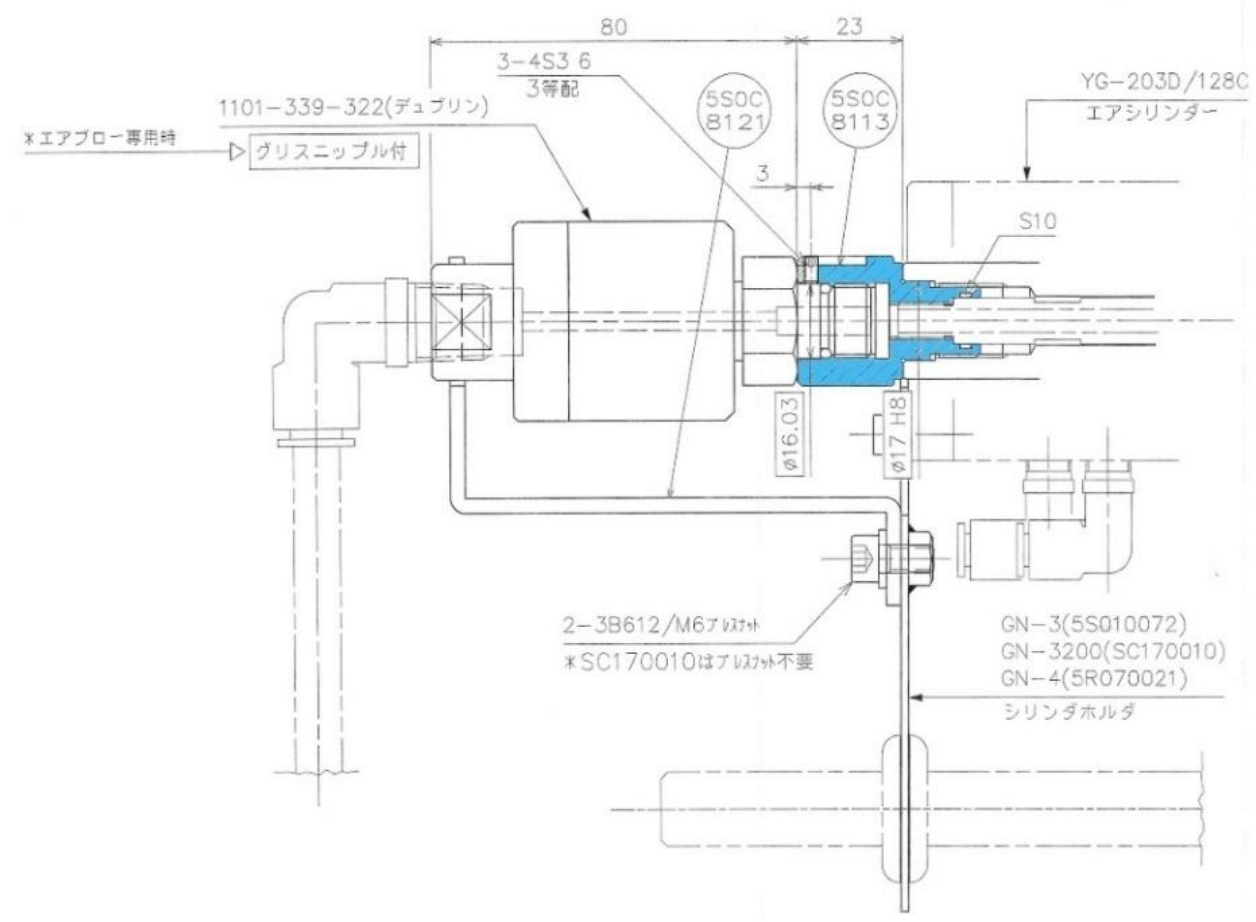

Obrázok 2 - Vytypovanie chybných dielov - medzikus zmiešavača 
Problémom vytypovaných dielov je dlhá doba dodania, niekedy aj šest' až osem týždňov. Pre výrobnú spoločnost' je takáto dížka odstávky ekonomicky závažná a preto sme sa rozhodli navrhnút' systém na zachytávanie vibrácií sústruhov pre zabránenie výroby nepodarkov, prípadne zabránenie vzniku náhlej poruchy a následnej dlhej dobe odstávky.

Riešením je umiestnenie senzorov na vretene sústruhu pre kontinuálne zachytávanie vibrácii. Na obrázku 3 je schematicky znázornené umiestnenie senzorov pre zachytávanie vibrácií. Zvolili sme dva smery merania pre najlepšie odhalenie chýb. Senzor A (červený štvorec) je umiestnený vo vertikálnom smere pre snímanie vibrácií na prírubách. Senzor B (modrý štvorec) znázorňuje druhý senzor vibrácii pre meranie vibrácií v axiálnom smere.

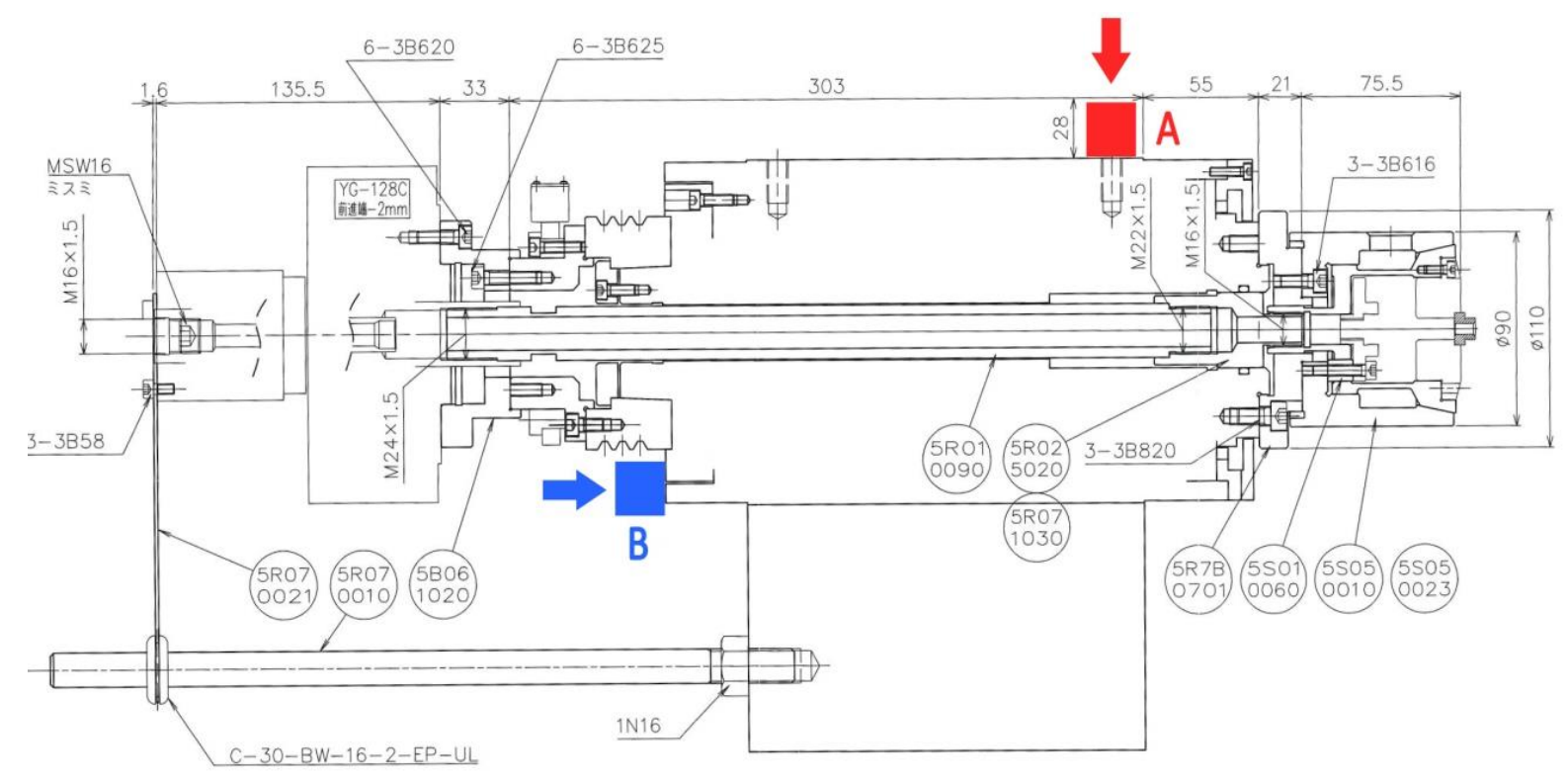

Obrázok 3 - Schematické zobrazenie senzorov

Na obrázku 4 môžeme vidiet' umiestnenie použitých senzorov na výrobnom stroji. Senzory sú pripevnené na pevné časti vretena tekutým kovom. Pre lepšie prenášanie vibrácií je pod senzormi odstránená farba. Z dôvodu obmedzených priestorov je $v$ radiálnom smere použitý menší senzor. 


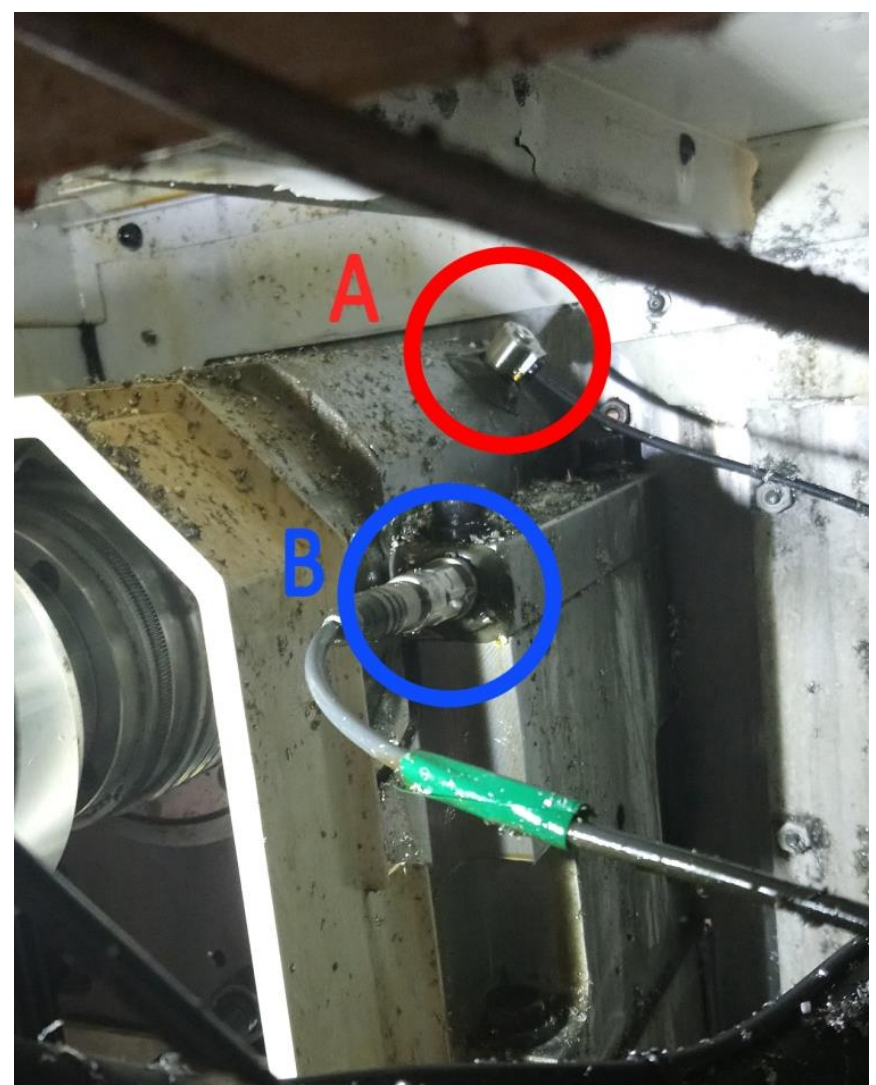

Obrázok 4 - Umiestnenie použitých senzorov na sústruhu

Pre zabezpečenie prediktívnej údržby sme vybrali vibračné senzory a vyhodnocovaciu jednotku od firmy IFM. V aplikácii prediktívnej údržby sme použili dva vibračné senzory, dvoch druhov, ktoré sú popísané nižšie. Využili sme senzory, ktoré dáta odosielajú do vyhodnocovacej jednotky VSE 100, od firmy IFM.

Na obrázku 5 je zobrazená vyhodnocovacia jednotka VSE 100, ktorá sa používa pre spol'ahlivé meranie vibrácií na strojoch a zariadeniach. Umožňuje vstup súčasne až pre štyri vibračné senzory. Obsahuje dva spínacie vstupy pre predbežný a hlavný poplach. [7]

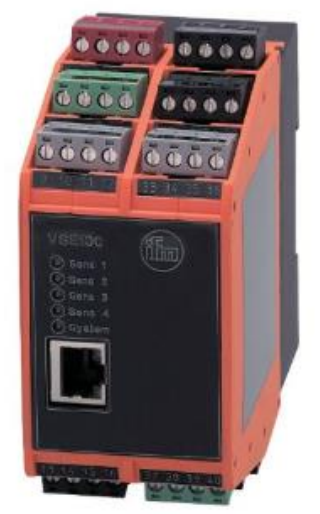

Obrázok 5 - Vyhodnocovacia jednotka VSE 100 
Prvý senzor, ktorý sme použili je akcelerometer - vibračný senzor VSA 001, od firmy IFM. Zabezpečuje spol'ahlivú detekciu vibrácií na strojoch a zariadeniach. Vyznačuje sa vel'kým teplotným rozsahom a vysokým stupňom krytia pre použitie $v$ náročných priemyselných podmienkach. Obsahuje kompaktné a robustné puzdro z nerezovej ocele. Umožňuje možnost' získavania informácie o rýchlosti a zrýchlení vibrácii. [8] Na obrázku 6 je zobrazený vibračný senzor VSA001, ktorý je použitý na meranie v axiálnom smere.

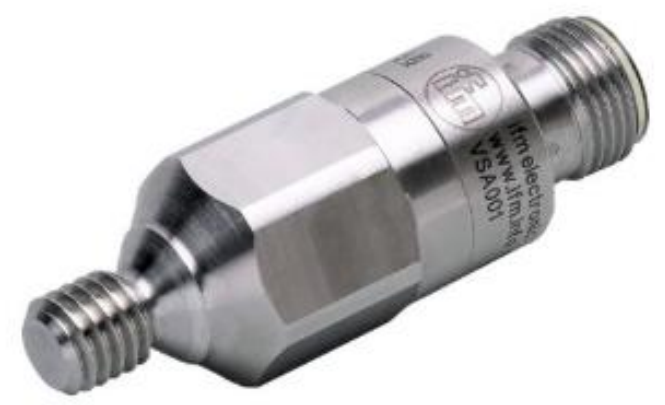

Obrázok 6 - Vibračný senzor VSA 001

Druhým vibračným senzorom je akcelerometer - VSA 005. Vyznačuje sa vysokou opakovatel'nost'ou merania a nízkou odchýlkou od charakteristiky. Taktiež patrí medzi najmenšie senzory a to zaručuje jeho použitie v obmedzených priestoroch v zástavbe vretena sústruhu. [9] Senzor VSA 005 použití pre snímanie vibrácií vo vertikálnom smere je znázornený na obrázku 7.

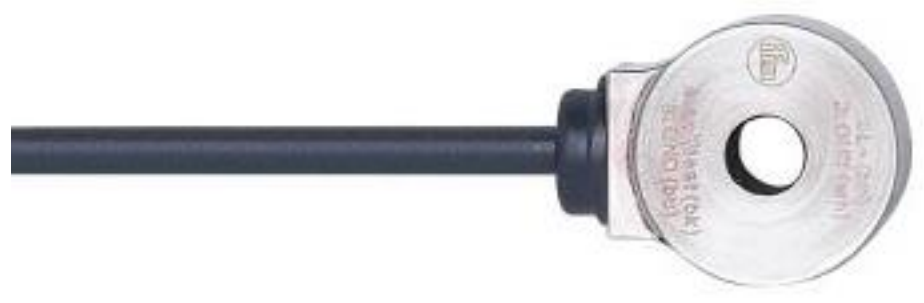

Obrázok 7 - Vibračný senzor VSA 005

Pre hodnotenie získaných údajov zo sústruhov sme zvolili software Octavis VES003, ktorý je zobrazený na obrázku 8 . Software je taktiež od spoločnosti IFM. Vd'aka softwaru môžeme zaznamenávat' vibrácie $v$ čase a vidiet' ako sa vreteno správa počas zat’aženia v prevádzke. 


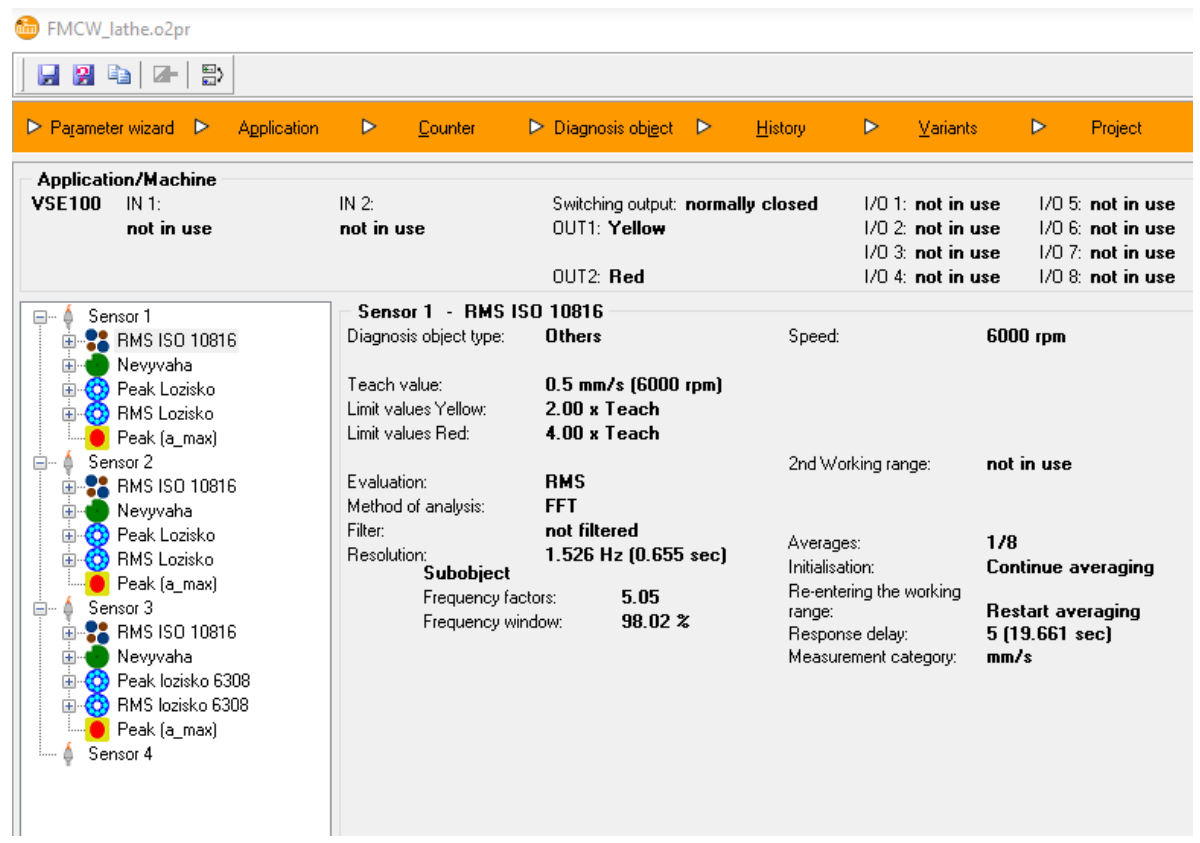

Obrázok 8 - Software Octavis VES003

\section{Záver}

V tomto príspevku sme sa zamerali na aplikovanie a následne využívanie prediktívnej údržby, ktorá ma v súčasnosti vel'ký význam. Základom tejto diagnostiky je kontinuálne, čiže neustále zaznamenávanie vibrácií, ktoré môžeme analyzovat' a odhalit' rôzne príčiny poškodenia stroja skôr ako nastane náhla porucha. Jedna sa o implementáciu snímačov, vyhodnocovacej jednotky a vyhodnocovacieho softwaru. Prediktívna údržba sa radí medzi bezdemontážnu diagnostiku, ktorá má vel'kú perspektívu do budúcnosti.

Základom príspevku bola diagnostika a analýza vretena sústruhu. Poškodenie vretena sústruhu sme zistili po pravidelnom meraní vyrobených komponentov, kedy sa hodnoty celkového hádzania nenachádzali v tolerancii. Po odstavení sústruhu a zhodnotení dostupných dát sme vytypovali diely, ktoré zapríčiňujú zle opracovanie polotovaru a následné nepresné hodnoty celkového hádzania. Medzi poškodené diely sústruhu, ktoré bolo potrebné vymenit' sme zaradili čelnú prírubu, prírubu upínania a taktiež zmiešavač emulzie. Sústruh bol odstavený šest' týždňov, kvôli dlhej dobe dodania náhradných dielov. $Z$ toho dôvodu sme sa rozhodli navrhnút' systém prediktívnej údržby, vd'aka ktorej vieme predíst' dlhej odstávke zariadenia a teda aj finančným stratám. Pre prediktívnu údržbu sme aplikovali vibračné senzory na vreteno sústruhu, ktoré snímajú vibrácie vo vertikálnom a axiálnom smere a výsledky ukladajú do aplikácie.

Aplikovaním prediktívnej údržby sme schopní odhalit' problémy skôr a to vd'aka analýze vibrácií a reálnym dátam z diagnostickej jednotky, čo má vel'ký vplyv na výkonnost' stroja a taktiež schopnost' plnit' zákazky včas. 


\section{Pod'akovanie}

Článok bol realizovaný vd'aka finančnej podpore z projektu VEGA 1/0051/20 a projektu KEGA 004TUKE-4/2020.

\section{Použitá literatura}

[1] MOBLEY, R.: Maintenance engineering handbook. 7th ed. New York: McGraw-Hill, 2008. ISBN 978-007-1546-461.

[2] HELEBRANT, F.: Technická diagnostika a spolehlivost, IV. provoz a údržba strojů. Ostrava. 2007. 127s.

[3] KREIDL, M.: Technická diagnostika: senzory, metody, analýza signálu. Praha: BEN - technická literatúra, 2006. Senzory neelektrických veličín. ISBN 80-730-0158-6.

[4] BILOŠ, J.: Aplikovaný mechanik jako součást týmů konstruktérů a vývojárů: studijní opora. Ostrava: Vysoká škola báňská - Technická univerzita Ostrava, Fakulta strojní, 2012. ISBN 978-80-248-2755-1.

[5] Fiix. What is predictive maintenance? [online]. [cit. 2021-09-09]. Dostupné na internete: $<$ https://www.fiixsoftware.com/maintenance-strategies/predictivemaintenance/>.

[6] HLAVATÁ, S.: Zvyšovanie prevádzkovej spolahlivosti výrobných strojov a zariadení: Bakalárska práca. Prešov: Fakulta výrobných technológií TU, 2018. 56s.

[7] Ifm. VSE100, Vyhodnocovací jednotka pro vibrační senzory. [online]. [cit. 2021-09-10]. Dostupné na internete: $<$ https://www.ifm.com/cz/cs/product/VSE100>.

[8] Ifm. VSA001, Akcelerometr. [online]. [cit. 2021-09-10]. Dostupné na internete: <https://www.ifm.com/cz/cs/product/VSA001>.

[9] Ifm. VSA005, Akcelerometr. [online]. [cit. 2021-09-10]. Dostupné na internete: <https://www.ifm.com/cz/cs/product/VSA005>. 